\title{
„BO MIŁOŚĆ MĘŻCZYZNY I KOBIETY JEST WALKĄ"1 SPOSOBY OBRAZOWANIA MIŁOŚCI W TWÓRCZOŚCI ZOFII NAŁKOWSKIEJ NA PODSTAWIE DZIENNIKÓW I KOBIET
}

Miłość była głównym tematem pierwszych tomów Dzienników oraz modernistycznych opowiadań i powieści Nałkowskiej - ona sama przyznała po latach: $w$ pierwszym okresie mego pisania miałam oczy obrócone $w$ głą siebie $-z$ surowym badaniem i jednocześnie z podziwem. (...) Byłam sama dla siebie miarq rzeczy, wystarczającym kryterium sq̨du o świecie. W ksiqżkach swych pisałam o miłości i myślałam, że każdy ma do niej prawo². Ze względu na młody wiek autorki ${ }^{3}$ można przypuszczać, że sposób, w jaki pisała wówczas o miłości, wynikał przede wszystkim nie z doświadczeń własnych, ale szeroko pojmowanego kontekstu kulturowego. Według Hanny Kirchner nie popetnimy nadużycia, gdy uznamy, że Schopenhauer w przeważnej mierze uksztaltował raz na zawsze światopoglad pisarki4, zaś sama Nałkowska często odwoływała się w Dziennikach do Nietzschego, Ibsena, Garborga, Maeterlincka, Freuda, Weiningera Strindberga Baudelaire'a czy Przybyszewskiego, których dzieła czytała często jeszcze w oryginale, nie czekając na polskie przekłady. Moderniści zwykli przedstawiać miłość jako walkę dwóch przeciwstawnych żywiołów - ich pesymistyczna wizja damsko-męskich relacji wyrastała z przekonania o odwiecznym antago-

\footnotetext{
1 August Strindberg.

2 Z. Nałkowska, O sobie, [w:] Z. Nałkowska, Widzenie bliskie i dalekie, Warszawa 1957, s. 14 .

3 Ostatnią kartę I tomu Dzienników zapisała w wieku 21 lat, a w chwili wydania Kobiet miała zaledwie 22 lata.

4 Kirchner Hanna, Modernistyczna młodość Zofii Nałkowskiej, „Pamiętnik Literacki” 1968, z. 1 , s. 76 .
} 
nizmie płci. W młodopolskiej literaturze i sztuce roi się od portretów femme fatale, schopenhauerowskiej wyrazicielki ślepego i drapieżnego gatunku, modliszki, niszczycielki, wampirzycy. Demonicznej kobiety, która już od zarania dziejów nienawidzi mężczyzn i żywi do nich nieskończoną pogardę . Postać ta miała być personifikacją męskich lęków związanych z narodzinami ruchu kobiet, dążeniem do emancypacji, zdobycia równych praw.

Pozostając w tym kręgu wpływów, całkowicie odrzuciła Nałkowska modernistyczny mizoginizm i stworzyła swój własny model kobiety wyposażyła ją w poczucie siły, pogardliwego, zwycięskiego panowania nad mężczyznq, nietzscheanski amoralizm, namiętnq potrzebę swobody ${ }^{6}$. Indywidualizm kobiet Nałkowskiej odzywa się także nutq wyzwania, dumy, jest przede wszystkim dla nich siłq $i$ obronq, czasem przejawia się $w$ egotycznym samouwielbieniu $(. . .)^{7}$. Bohaterki Nałkowskiej są więc godnymi przeciwniczkami mężczyzn, a raczej mogłyby być, gdyby nie ograniczenia społeczne, wynikające $z$ odmiennej dla każdej płci moralności. Podwójne standardy są według Nałkowskiej przyczyną wszystkich nierówności między kobietami i mężczyznami, one też czynią z miłości ciągłą walkę o władzę (Świat dzieli się na smutnq szlachetność i rozkoszny brud. Kobiety majq do wyboru tylko jedno lub drugie, mężczyznom wolno swobodnie przechodzić od jednego do drugiego. D, 23).

Odtwarzając sposoby obrazowania miłości w twórczości Zofii Nałkowskiej analizowałam jednostki leksykalne nazywające uczucie i metaforyczne konkretyzacje miłości. Podstawę materiałową stanowiły dla mnie I tom Dzienników i Kobiety ${ }^{8}$, pierwsza z modernistycznych powieści Nałkowskiej. O takim doborze materiału zdecydował fakt, że Kobiety można właściwie uznać za powieść autobiograficzną - początkująca wówczas pisarka bardzo często sięgała do swoich własnych przeżyć i doświadczeń, kształtując losy postaci literackich. Główna bohaterka Kobiet jest

5 Zob. A. Chałupnik, Płeć i charakter. Dziewiętnastowieczne konceptualizacje różnicy płci, [w:] A. Chałupnik, Sztandar ze spódnicy. Zapolska i Nałkowska: o kobiecym doświadczeniu ciała, Warszawa 2004.

6 Kirchner Hanna, Modernistyczna młodość Zofii Nałkowskiej, „Pamiętnik Literacki” 1968, z. 1 , s. 70 .

7 Tamże, s. 79.

8 Wszystkie przywoływane fragmenty utworów pochodzą z wydań Z. Nałkowska, Dzienniki I, 1899-1905 w opracowaniu H. Kirchner, Warszawa 1975, Czytelnik, Z. Nałkowska, Kobiety, red. Z. Mycielska-Golik, Warszawa 1976, Czytelnik. Dla przytaczanych przykładów stosowane są skróty D (Dzienniki) i K (Kobiety). 
literackim portretem autorki, posiada nie tylko jej złote włosy, ale i zbliżoną biografię, podobne myśli i zmagania wewnętrzne, a w obiektach jej uczuć bez trudu można rozpoznać mężczyzn, których uczuciem darzyła sama Nałkowska. Według A. Górnickiej-Boratyńskiej można powiedzieć, że Nałkowska pisała wtedy w pewnym sensie jeden tekst niezależnie od formy - prywatne zapiski stanowity podstawe powieści, powieści przyjmowaty charakter wewnętrznej biografii, teksty publicystyczne podejmowały myśli formułowane $w$ dziennikach i fabularnie ilustrowane $w$ powieściach ${ }^{9}$.

Sama miłość rozumiana jest tu jako 'głębokie przywiązanie do kogoś lub czegoś, umiłowanie, ukochanie kogoś, czegoś; gorące, namiętne uczucie do osoby płci odmiennej' ${ }^{10}$. Analizie poddane zostały tylko te jednostki leksykalne nazywające uczucie i metaforyczne sposoby kreowania miłości, które związane są z miłością partnerską, pojmowaną jako 'platoniczny lub erotyczny stosunek emocjonalny do osoby odmiennej płci (tu relacje małżeńskie)'11. Inspiracją (wskazówką) metodologiczną w tym zakresie był dla mnie artykuł Językowy obraz miłości w utworach Stefana Żeromskiego, autorstwa Grażyny Filip i Marii Krauz ${ }^{12}$.

Pisząc o miłości jako pewnej idei, upragnionym choć niezaznanym dotąd uczuciu, posługiwała się Nałkowska bezpośrednią nazwą tego uczucia bądź wywodzącymi się z tego samego pola semantycznego leksemami czasownikowymi: miłość, kochać, zakochać się. Wyrazy te pozbawione były jakichkolwiek określen, nie dopełniały ich żadne epitety. Miłość i kochanie były więc na tym etapie dla Nałkowskiej abstraktami, których dotąd nie doświadczywszy, nie potrafiła skonkretyzować.

O miłości marzyły zgodnie Nałkowska i jej Janka - przywoływały ją zgodnie od pierwszych kart dziennika i powieści:

O Boże, jakże ja chciałabym się zakochać, by przestać być dla siebie samej celem myśli i pragnień, przedmiotów zachwytów. D, 73

O Boże, jak ja bardzo chcę kochać! D, 75

9 A. Górnicka-Boratyńska, Stańmy się sobq. Cztery projekty emancypacji (1863-1939), Izabelin 2001, s. 148-9.

10 Słownik języka polskiego, red. M. Szymczak, t. II L-P, Warszawa 1988, s. 77.

11 G. Filip, Językowy obraz miłości w Ludziach bezdomnych i Przedwiośniu Stefana Żeromskiego. Metaforyczne obrazy miłości, "Zeszyty Naukowe Uniwersytetu Rzeszowskiego. Seria Filologiczna. Dydaktyka 4", z. 32/2005, s. 150.

12 Zob. G. Filip, M. Krauz, Językowy obraz miłości w utworach Stefana Żeromskiego, [w:] Światy Stefana Żeromskiego, red. M. Olszewska i G. Bąbiak, Warszawa 2005. 
A ja koniecznie potrzebuję, by mię ktoś kochał; inaczej czuję się samotna i zbyteczna. D, 255

Zaczynam się lękać, że nie spotkam na drodze miłości - i doznaję takiego uczucia, jak gdybym sobie wyobraziła, że jestem kaleką. Być niezdolną do miłości - to jakiś wstrętny, fizjologiczny brak. (...) Jak ja strasznie pragnę być osią czyjegoś życia, motywem i celem. D, 169

Gdy w końcu nadeszła, okazała się bliższa przekleństwu niż szczęściu, przyniosła trwogę - nie szczęście, wieczną szamotaninę - nie spokój. Miłość, o której opowiada Nałkowska, jest zawsze niedobra ${ }^{13}$ - to system tortur, walka i w końcu śmierć. Wiernie towarzyszą jej wstręt i nienawiść. Na tym etapie miłość nie jest już wiec tylko ideą, marzeniem, a dobrze znanym zbiorem emocji o różnych barwach. Leksemy miłość i kochać są tu zestawiane z nazwami stanów towarzyszących miłości. Co ciekawe - stany te wydają się miłości zupełnie obce, bliskie zaś walce i okrutnym zmaganiom $\mathrm{z}$ wrogiem.

A miłość moja patrzy obłąkanymi z trwogi oczami w swój nakazany sobie kres - - K, 148

Ja mogłabym być sto razy lepsza, niż jestem, gdybym się nie bała... K, 143-4

A ja szamocę się $\mathbf{w}$ tej miłości, jak wzbity nad obłoki latawiec szamoce się na nitce, trzymanej w palcach przez rozbawione pacholę. K, 146

W gruncie rzeczy wszystkie kobiety są jednakowe - za jednym uganiają się przez całe życie - i od tego samego giną --

Miłość? - zapytałam niezręcznie, symulując obojętność. K, 132

Nienawidzę cię tak, jak cię kocham, bardziej nienawidzę! K, 27

A rano na Janusza patrzę z nienawiścią i wstrętem. Pastwię się nad nim, chociaż on właściwie nic nie winien. Mszczę się na nim za to, że dusza moja błąka się samotnie po polach lodowych i roi jeszcze swe zimne, srebrne sny - i szuka próżno duszy bratniej. K, 25

Witold wciąż był przy mnie - subtelny, dobry - tkliwością maskował wstręt, który musiałam w nim budzić wtedy. K, 92

Ogarnął mię szalony wstręt, bo uczułam w nim budzącego się mężczyznę, w tym wyrostku - strasznie wysokim i cienkim, w zniszczonej gimnazjalnej czapce i brudnej bluzie, o nogach długich jak patyki, beznadziejnie ginących w olbrzymich butach. D, 102

13 Taki tytuł otrzyma powieść uważana przez wielu krytyków za najdojrzalszą w całej jej twórczości. 
Ostatecznie ogarnął mnie wstręt do tego strasznie długiego wyrostka, w którym zaczyna budzić się mężczyzna. Jest $\mathrm{w}$ tym cos tak obrzydliwego. D, 113

Połączenia leksemów miłość i kochać z epitetami wartościującymi pozytywnie zdarzają się tu tylko $\mathrm{w}$ formie zaprzeczeń - kochać nie można spokojnie, a miłość nie jest święta ani idealna:

Witoldzie - bądź wspaniałomyślny, pozwól mi wypocząć od tego wiecznego mienia się na baczności, pozwól mi się chociaż przez chwilę spokojnie kochać. $\mathrm{K}, 144$

Miłość nie ma nic wspólnego z wzajemnym uwielbieniem, z przyjaźnią, $\mathrm{z}$ „braterstwem dusz". (...) Miłość święta, idealna, miłość z przysięgą kościelną - jakie to kłamstwo. D, 24

Jaka zatem jest miłość? Co dla człowieka oznacza kochać? Miłość to system tortur, bo kochając wijemy się w szczęściu jak w bólu, rozkoszą się zachłystujemy, dławimy, nie mogąc przestać - sączymy ją do konwulsji i śmierci. Przekazanie ukochanego innej kobiecie jest tu nie udręką, a wyzwoleniem, słodką zemstą - wreszcie ona - nie ja - będzie konać w konwulsjach.

Pragnę dlatego, byś ty mogła zostać jego żoną, byś i ty poznała cały ten system tortur, byś się tak wiła, jak ja, w promieniach tego szczęścia, byś, jak ja, piła tę rozkosz pełnymi krużami - jeszcze, jeszcze - byś się zachłystywała falami piołunu, dławiła pod śmiertelnym prześcieradłem kwiatów, byś piła ten aromat, rozkosz, truciznę, war - do konwulsji, do śmierci... byś później tez przez zemstę mogła ustąpić go innej. K, 138

Jak już wspomniałam, w twórczości Nałkowskiej dominuje obrazowanie miłości jako walki - temu obrazowi podporządkowane są wszystkie sposoby ukazywania tegoż uczucia. Jest to jednak walka, do której przystępują godni siebie przeciwnicy. Bohaterki Nałkowskiej w niczym nie ustępują mężczyznom, a natura kobieca nie przynosi więcej ograniczeń niż męska - tym bowiem co różnicuje status płci, jest mieszczańska obyczajowość, moralność, kultura. I choć kobiety w miłości mają trudniej, nie znaczy to, że obca jest im chęć zawładnięcia ukochaną osobą. Wyposażone w nietzscheańską świadomość swej siły, czując moc i potęgę, pragną pełni władzy nad swoim mężczyzną.

Obrazowaniu miłości służą słownictwo nazywające relacje kobiet i mężczyzn, a także metaforyczne nazwy stron tej miłosnej walki. 


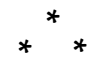

Bardzo często się zdarza, że Nałkowska głosem swoim lub któregoś z bohaterów nazywa wprost to, co się dzieje między mężczyzną i kobietą walką lub walczeniem:

Czy pani nie uważa, że między nami jest walka?

Może być - mówię lekceważąco. K, 11

Za którymś razem wyzwałam na walkę jego oczy, wytrzymałam wzrok, by go upewnić o mym zupełnie wrogim nastroju. K, 108

Jaka niesłychana przewaga! Jakże potwornie, potwornie nierówna walka! K, 168

W ogóle stosunek nasz to łańcuch wzajemnie wykluczających się z obu stron niechęci, sympatii, zachwytu, wstrętu etc. W pewnej mierze jest on też walką. D, 136

Obecnie nie uśmiechamy się już do siebie ze słoneczną dobrocią, jest między nami głucha, ale niegroźna walka. D, 321

Ja nie walczę już z tobą, nie zdobywam - ja błagam ciebie, jak niewolnik, zaklinam na wszystko - bądź moją żoną... K, 38

Znowu probujesz walczyć ze mną, choć wiesz, ze jesteś w mojej mocy. D, 131

Z tego samego pola semantycznego pochodzą takie jednostki leksykalne, jak wyzwanie i wieczny antagonizm, czy - przywodzące na myśl polowanie - węszenie żeru:

Odchodzi zawsze pobity, pokorny, kryjąc pod serdecznością pożegnalnego pocałunku wzbierającą nienawiść wiecznego antagonizmu. K, 152

Janusz zrozumiał od razu wyzwanie - jest zły, czeka w milczeniu, z trudem utrzymuje konia $\mathrm{w}$ tym samym miejscu, bym musiała pierwsza obrócić ku niemu głowę. $\mathrm{K}, 10$

Paru panów podeszło przywitać się z nami. byli trochę zdziwieni i z pewnym rozrzewnieniem patrzyli na Ginę. Wyglądali, jakby węszyli żer. K, 157

Dalsze słownictwo obrazujące relacje kobiet i mężczyzn gromadzi się wokół trzech głównych pól semantycznych, ściśle z walką związanych dążenia do dominacji, zyskania przewagi nad przeciwnikiem (którym jest tu ukochana osobą) oraz działaniami, które można chyba uznać za akty reakcyjne wobec powyższego - oporem i uległością. 
Miłość to walka o panowanie, zdobycie władzy nad drugim człowiekiem. Ten aspekt kochania musiał być dla Nałkowskiej niezwykle ważny, skoro już w dwóch pierwszych jej dziełach zobrazowała go na tyle różnych sposobów. Do pierwszej grupy należałoby zaliczyć pozbawione wartościowania leksemy i połączenia wyrazowe oznaczające zdobycie władzy nad drugą osobą, których użyto by także do opisu walki innych przeciwników niż kochankowie, może nawet wojennych praktyk żołnierzy. Znajdą się tu takie wyrazy i zwroty, jak: panować, zapanować i panowanie, zwycięstwo, rozbroić, uśpić czujność, wziąć górę i stawiać warunki:

Ktoś musi panować - a panować mogę tylko ja. D, 344

A inny jeszcze nastrój - jaskrawy, gorący, kiedy kocham silniej, choć nie tak głęboko, nie myślę ani o poddaniu się jego władzy, ani o panowaniu, ani o krzywdzie mej, ani o zemście - tylko kocham. D, 340

Mówi wiele o miłości - w sposób naturalistyczny, prawie - medyczny, tak iż co chwila robi mi się zimno. Prawdopodobnie to jego metoda, chce tym sposobem zapanować nade mną. D, 247

Może ostatecznie potrafię się obejść bez mężczyzny, ale to będzie tylko moje zwycięstwo. D, 25

Pewna zwycięstwa, mówię cichym głosem: „nie" - i uśmiecham się. K, 27 Ja zaś smutna jestem moim zwycięstwem. $\mathrm{K}, 27$

Mogę rozbroić go jednym krzykiem bólu lub trwogi, ale milczę. Potrzeba mi dziś silnych wrażeń. K, 27

Czyż na całej ziemi nie ma człowieka, który zdołałby choć na chwilę uśpić moją czujność? K, 32

Teraz ja wzięłam górę - może źle, żem tego nie zużytkowała. D, 136

Nie robisz żadnej ofiary, nie poświęciłaś dla mnie nic, więc nie masz prawa stawiać warunków... K, 189

Kolejne określenia łączą się z leksemem siła - do tej grupy należeć będą: siła, która ujarzmi (wyrażenie nawiązujące do nietzscheańskiej kategorii siły) i powszechnie stosowany frazeologizm próbować sił:

Ładny jest. Ale nie radzę pani próbować na nim swych sił - zajęty już. K, 34-5

$\mathrm{O}$,jakże znużona jestem na wyżynie”, jakże chciałabym znaleźć siłę, która ujarzmiłaby moją... K, 28

Gdybym tego człowieka nie kochała, to musiałabym go nienawidzić. Bo to jest jedyna siła, która byłaby w stanie ujarzmić moją. K, 64 
Osobną kategorię stanowią określenia zawierające konstrukcje być plus przymiotnik lub rzeczownik - być potrzebnym, być osią życia, być motywem, być celem. Dominacja nad ukochaną osobą oznacza tu bycie jej niezbędną do życia, wyznaczanie jego dalszego biegu, kierunku, decydowanie o przyszłości:

Zaczynam się lękać, że nie spotkam na drodze miłości - i doznaję takiego uczucia, jak gdybym sobie wyobraziła, ze jestem kaleką. Być niezdolną do miłości - to jakiś wstrętny, fizjologiczny brak. (...) Jak ja strasznie pragnę być osią czyjegoś życia, motywem i celem. D, 169

Odejść nie mogę, bo ten człowiek jest mi teraz potrzebny jak powietrze. $\mathrm{K}, 148$

Liczną grupę stanowią leksemy i połączenia wyrazowe o negatywnym zabarwieniu emocjonalnym, ukazujące stosunki kobiet i mężczyzn jako swego rodzaju grę. Aby wygrać, należy partnera zhołdować, traktować z góry, lekceważąco i po królewsku, utrzymywać przewagę, by móc uczynić go swym niewolnikiem i rzucić pod stopy. Ta gra jest bardzo niebezpieczna - można nią zepsuć czyjeś życie, a jeśli nie całe, to kilka jego lat:

Od dawna zwątpiłam zupełnie, by znalazł się jaki mężczyzna, któremu bym ja wbrew woli ulegała, który miałby moc mię „zhołdować”, zdawało mi się, ze względem każdego zajmę takie stanowisko, jak względem tego całego szeregu, jaki się przed mym wzrokiem przesunął tej zimy. D, 136-7

Traktuję go z góry, lekceważąco, po królewsku. D, 302

Witold mnie nienawidzi, a ja go kocham po prostu do szaleństwa - za jego oryginalność i ten czarowny despotyzm, jakim on rzuca mię prawie pod swe stopy. D, 135

Kiedy mi powiedziałeś: „nie dawaj mi nad sobą przewagi, bo zrobię z ciebie niewolnicę, a z chwilą, gdy Marta stała się moją niewolnicą, przestałem ją kochać" - to ja postanowiłam tej przewagi Ci nie dać, stałam się bardziej skryta i wynaturzona, i nieskończenie samotna (...) K, 144

Jaka niesłychana przewaga! Jakże potwornie, potwornie nierówna wal$\mathrm{ka}$ ! K, 168

Policzyłam. Widziałam go siedem razy w życiu. A zepsuł mi trzy lata życia. $\mathrm{D}, 271$

Część leksemów związanych damsko-męskimi potyczkami na stałe zadomowiła się już w polszczyźnie - jak czarować, zabawić się i zdobywać: 
Ten człowiek znowu zaczyna mię czarować. D, 302

Chce się zabawić, ale tym razem już mu się nie uda. D, 302

Jeszcze później - przychodzi mi na myśl, ze między mężczyzną i kobietą jest pewna zasadnicza różnica, mianowicie, że $w$ miłości mężczyzna zdobywa, a kobieta ulega, ze kobieta jest związana wstydem, godnością kobiecą itd. D, 92

Ostatnią grupę stanowią leksemy negatywnie nacechowane, oznaczające celowe krzywdzenie osoby, znajdującej się w naszej mocy - mścić się, pastwić, dręczyć i piętnować czyjąś pokorę:

Mszczę się na nim za to, że dusza moja błąka się samotnie po polach lodowych i roi jeszcze swe zimne, srebrne sny - i szuka próżno duszy bratniej. K, 25

Pastwię się nad nim, chociaż on właściwie nic nie winien.

Pastwiłam się nad nim jak zwierzę - i z rozkoszą widziałam, jak się pasował ze sobą, jak się męczył - chociaż przez chwilę czuł to, co ja. D, 313

A wiem, ze Janusz, dręczony przeze mnie w ciągu dnia całego, jest $u$ kresu sił. K, 26

Ale gdy tylko ustąpię coś z praw moich, ty okazujesz brak wspaniałomyślności i piętnujesz tryumfalnie moją pokorę. K, 143-4

Równie bogato zobrazowany został akt uległości wobec siły miłości, poddanie się władzy ukochanej osoby, pełne zatracenie. Ponownie wypada tu wskazać pierwszą grupę wyrazów emocjonalnie nienacechowanych, którymi posłużyć się można do opisu zmagań wojennych nie tylko na polu miłości - składać broń przed walką, poddać się władzy, ustąpić z praw czy utracić niepodległość:

(...) i nie daje mi nawet zadośćuczynienia $\mathrm{w}$ zemście, $\mathrm{w}$ mierzeniu się $\mathrm{z}$ równym wrogiem, bo składa broń przed walką. D, 344

A inny jeszcze nastrój - jaskrawy, gorący, kiedy kocham silniej, choć nie tak głęboko, nie myślę ani o poddaniu się jego władzy, ani o panowaniu, ani o krzywdzie mej, ani o zemście - tylko kocham. D, 340

Ale gdy tylko ustąpię coś z praw moich, ty okazujesz brak wspaniałomyślności i piętnujesz tryumfalnie moją pokorę. K, 143-4

Czyż to nie ta trwoga raczej, która w krew nam już weszła, trwoga przed rzeczywistością, czyż to nie wieczna potrzeba grania roli obleganej fortecy, która po to tylko broni swej niepodległości, by ją tym drożej utracić... K, 109

Drugą kategorię tworzy słownictwo powszechnie stosowane w opisie gry miłosnej, odwołujące się do stereotypu mężczyzny-zdobywcy i uległej kobiety jako obiektu jego podbojów, łowów: 
Od dawna zwątpiłam zupełnie, by znalazł się jaki mężczyzna, któremu bym ja wbrew woli ulegała, który miałby moc mię „zhołdować”. D, 136-7

Jeszcze później - przychodzi mi na myśl, ze między mężczyzną i kobietą jest pewna zasadnicza różnica, mianowicie, że w miłości mężczyzna zdobywa, a kobieta ulega, ze kobieta jest związana wstydem, godnością kobiecą itd. D, 92

Kolejna grupa to znów leksemy pozostające w związku z nietzscheańską kategorią potęgi, ponadludzkiej siły, jaką obdarzeni się niektórzy ludzie. U Nałkowskiej moc ta służy przede wszystkim zniewalaniu partnera gry miłosnej, który oddając się w moc ukochanej osobie, uznaje nad sobą jej władanie, korzy się przed jej siłą:

Dziwne złudzenie - czy sugestia - uczułam się taką słabą, jak on mówił, taką strasznie $\mathbf{w}$ jego mocy... K, 191

Znowu probujesz walczyć ze mną, choć wiesz, że jesteś w mojej mocy. D, 131

Ale z chwilą, kiedy on zaczyna być $\mathbf{w}$ mojej mocy - ja się nudzę. D, 285

Bierzemy wszystko strasznie poważnie (...) To nas oddaje $\mathbf{w}$ ich moc.

A teraz zazdroszczę mu niesłychanej rozkoszy ukorzenia się przed moją siłą. K, 27

W miłości pojmowanej jako walka jest miejsce tylko dla jednego zwycięzcy. Wygrywa zawsze ten, komu uda się zdobyć przewagę nad drugą stroną:

Teraz już - od czasu twej spowiedzi - boję się dać ci przewagę nad sobą, a nie wierzę $w$ miłość przy utrzymaniu szans równych. K, 143-4

Kiedy mi powiedziałeś: „nie dawaj mi nad sobą przewagi, bo zrobię z ciebie niewolnicę, a $\mathrm{z}$ chwilą, gdy Marta stała się moją niewolnicą, przestałem ją kochać" - to ja postanowiłam tej przewagi Ci nie dać, stałam się bardziej skryta i wynaturzona, i nieskończenie samotna (...) K, 144

Przegrana oznacza konieczność rezygnacji z siebie, czyli ciągłego stosowania się do kogoś, robienia ofiary, nieustannych poświęceń:

Musisz mię brać takim, jakim jestem - musisz się starać mię poznać i ty do mnie raczej się stosować niż ja do ciebie... K, 189-90

Nie robisz żadnej ofiary, nie poświęciłaś dla mnie nic, więc nie masz prawa stawiać warunków... K, 189 
Osobie zakochanej obce są stany szczęścia, a miłość wywołuje uczucie obezwładnienia, opanowania i pobicia, słabości, bierności i ujarzmiania; prowadzi do poczucia osamotnienia, wynaturzenia, wreszcie wyczerpania nerwowego. Wśród tych emocji nie ma nawet jednej o neutralnym czy pozytywnym nacechowaniu.

Pod tym względem jestem jego pierwszą miłością, nigdy nie czuł się tak zupełnie obezwładniony, opanowany. D, 329

Janusz jest teraz pokorny i bierny. K, 32

Odchodzi zawsze pobity, pokorny, kryjąc pod serdecznością pożegnalnego pocałunku wzbierającą nienawiść wiecznego antagonizmu. K, 152

Dziwne złudzenie - czy sugestia - uczułam się taką słabą, jak on mówił, taką strasznie w jego mocy... K, 191

Wydawał mi się bardzo inercyjny, jako charakter, i dobrze ujarzmiony - K, 147

Czasami, gdy długo siedzimy we dwoje wieczorem, zasypia $\mathrm{z}$ głową na mych kolanach zmożony wyczerpaniem nerwowym. K, 32

(...) to ja postanowiłam tej przewagi Ci nie dać, stałam się bardziej skryta i wynaturzona, i nieskończenie samotna (...) K, 144

Ostatnią z grup stanowi słownictwo oznaczające całkowite poddanie, rezygnację z dumy, człowieczeństwa, nawet siebie - w imię miłości. Mamy tu więc oddanie się na laskę, czołganie jak pies i padanie przed kimś twarzą czy na twarz. Zachowania te wydają się mieć więcej wspólnego z czczeniem bóstwa niż uleganiem sile miłości.

Mdlejąc ze zmęczenia, oddaję się pokornie na łaskę jego porywającej, dzikiej siły. K, 20

Przy tym jest tak, ze podczas gdy on jest niedostępny i ambitny, ja czołgam się jak pies. D, 129

A Janusz z głośnym krzykiem pada twarzą na dno łodzi. K, 27

Idę do niego, kopiąc się przez zaspy śnieżne - i padam na twarz u stóp jego. $K, 67$

Najmniej licznie reprezentowane są w analizowanych tekstach obrazy oporu, sprzeciwu wobec zamachu na niezależność, wolność ze strony partnerki czy partnera. Największą grupę stanowią tu leksemy i połączenia wyrazowe wyrażające stan ciągłego oczekiwania, napięcia - czuwać, czuwanie, mienie się na baczności, podrabianie nastrojów, ukrywanie prawdy: 
Jak bym ja strasznie chciała - wiesz, z tych snów szkarłatnych kiedy się budzę - spotkać się z mądrymi, spokojnymi, pełnymi świadomości oczami - bo musi ktoś czuwać, by mógł spać ktoś. K, 189

I ogarnia mię przerażenie, ze oto zasnęłam na chwilę, a nad bezpieczeństwem moim nie czuwał nikt... K, 189

A ja większe natężenie twojej miłości okupuję ceną nieustannego czuwania, podrabiania nastrojów, ukrywania prawdy. K, 144

Witoldzie - bądź wspaniałomyślny, pozwól mi wypocząć od tego wiecznego mienia się na baczności, pozwól mi się chociaż przez chwilę spokojnie kochać. K, 144

W drugiej kategorii znalazły się zwroty bronić niepodległości i opierać wszystkimi siłami, oznaczające aktywny opór, obronę przeciw wrogim działaniom, nienacechowane emocjonalnie. Zaliczyć tu chyba można także poetycki zwrot dusza wysuwa kolce, stanowiący znaczeniowy ekwiwalent praktyk obronnych:

Czyż to nie ta trwoga raczej, która w krew nam już weszła, trwoga przed rzeczywistością, czyż to nie wieczna potrzeba grania roli obleganej fortecy, która po to tylko broni swej niepodległości, by ją tym drożej utracić... K, 109 Przecież ty zmusiłeś ją wprost do małżeństwa - pamiętam, ze opierała się temu wszystkimi siłami... K, 134

(...) i pomyślałam, ze Mędrzecki jest człowiekiem, przeciw któremu cała moja dusza wysuwa kolce - i że jemu nigdy w życiu nie powiem ani słowa prawdy. D, 241

Sprzeciwem można nazwać także postawę niedostępności i ambicji, prezentowaną przez jednego $\mathrm{z}$ bohaterów:

Przy tym jest tak, ze podczas gdy on jest niedostępny i ambitny, ja czołgam się jak pies. D, 129

O ile słownictwo obrazujące relacje kobiet i mężczyzn w takim samym stopniu odnosi się do zachowań, myśli i stanów psychicznych przedstawicieli obu płci, to już leksyka użyta w metaforycznych portretach kobiet i mężczyzn w większym stopniu sięga do językowych stereotypów (mężczyzny-wojownika, zdobywcy i kobiety-obiektu, nie podmiotu działań). 
Pozostając wierna metaforyce walki, w przeważającej części maluje Nałkowska obrazy mężczyzn niebezpiecznych, wywołujących niepokój i uczucie zagrożenia. Ich siła jest różnego rodzaju: niekiedy to dzika i nieujarzmiona siła natury - tu dominują porównania do niebezpiecznych zwierząt - wilka, konia, lwa:

Gdy choć na chwilę zaśnie $\mathrm{w}$ nim zwierzę, jest dobry i miły jak dziecko. K, 16

A Janusz na cmentarzu robi się smutny i rozprawia na temat znikomości rzeczy ziemskich. To ładne zwierzę boi się śmierci. K, 24

(...) $\mathrm{w}$ duszy mam tylko obiektywny podziw dla tego rasowego zwierzęcia. D, 341

Czasami Janusz jest łagodny jak młody, oswojony wilk. Z oczu znika mu akcent dzikości. K, 12

Z nim lubię tańczyć najbardziej. Ponosi mię jak rozhukany koń. K, 19

Pewien student - wielki, dobry, ładny, z wielka grzywą jak lew, wyróżniał mię manifestacyjnie. D, 219

Olśniewałam go tanimi paradoksami - i zdobyłam sobie takiego głupiego, ładnego lwa. D, 219

Ty śliczny, młody chłopcze z połyskującymi jak u wilka oczami - czemuś ty nie wiedział, ze... K, 57

Innym razem wskazany jest tylko jeden $\mathrm{z}$ elementów zwierzęcego ciała, w którym ujawniać ma się nieposkromiona męska natura - oczy, zęby i nozdrza:

Janusz idzie koło mnie, jak żywioł. Płonącymi oczami śledzi moje spojrzenie. $\mathrm{K}, 34$

Robi na mnie ze swymi drgającymi nozdrzami wrażenie ładnego, rasowego zwierzęcia. K, 12

Widzę teraz Janusza. Jest ładny. Nozdrza drgają mu ze złości. Ma jasną dżokejkę, obcisłe spodnie i buty z lakierowanymi cholewkami. K, 11

Ryś patrzy gorąco, rusza nozdrzami i pokazuje zęby (...) D, 321

(...) a on grzebie nogami piasek jak młody, rasowy koń, nozdrza mu drgają, krew gra, ściska mię $\mathrm{w}$ objęciach jak $\mathrm{w}$ kleszczach, aż $\mathrm{z}$ piersi wydzierają mu się dławione łkania namiętności. D, 341

Oczy - zwykle lśniące migotliwie - matowieją mu teraz, jakby schną - jakby ich żar przygaszony sam siebie przepalał. Spuszcza je raz po raz pod mym wzrokiem i stara się poczciwie uśmiechać, ale w tym spokojnym uśmiechu jego białe zęby połyskują źle. K, 12 
Do dzikiej siły odwołują się też obrazy mężczyzn jako barbarzyńców, krewnych człowieka pierwotnego:

Ten pęd szalony i odurzające swą monotonną jaskrawością dźwięki skocznej melodii podniecają go, jak ludzi pierwotnych tańce wojenne. K, 20

Typowy człowiek pierwotny z okresu koczowniczego łowiectwa.

Mężczyźni jawią się także jako nieludzkie byty - obdarzone siłą maszyn, monumentalne twory, obezwładniające człowieka swą wielkością, miażdżące wręcz. Są wtedy czymś wrogim, nienawistnym, groźnym, magnetyzującym i niedookreślonym $\mathrm{w}$ swej postaci:

Rosławski nie robi na mnie wrażenia mężczyzny, tylko jakiejś siły mechanicznej, czegoś takiego, co jest wrogie i nienawistne, groźne i magnetyzujące. $\mathrm{K}, 55$

W tym samym polu semantycznym pozostają określenia pociąg, powóz, posąg bazaltowy, odnoszące się do jednego z bohaterów Kobiet.

Mam wrażenie, że stoję na szynach w mroźną zadymę zimową i wśród wycia wichru słyszę łoskot rozpędzonego pociągu, ale nie uciekam. K, 55

Patrzę w zimne obiektywne oczy nadjeżdżającego powozu, który mię za chwilę rozmiażdży - i nie uciekam - jak w jakimś męczącym śnie - bo nie mogę wzroku oderwać od tych spokojnych, lśniących oczu. Stoję bezbronna, oczekująca - z nienawiścią i pokorą. $\mathrm{K}, 55$

W dali, na tle stygnącej zorzy, stoi wielki posąg bazaltowy. Nie boi się ani pustki bezkresnej, ani chłodnego światła zórz polarnych, ani srebrnych oczów czasu. Spokojny i nieulękniony. To Rosławski. K, 67

Nawet jeśli mężczyźni nazywani są ludźmi, to jednak zawsze ludźmi wrogimi, obdarzonymi władzą, pełniejszymi w swym człowieczeństwie od kobiet - zawsze więc przeciwnikami w walce:

I dlaczego, myślałam jednocześnie, z jakiej przyczyny uważam za wroga tego smukłego, ładnego chłopca, chociaż on nie żywi w stosunku do mnie żadnych złych intencji - nic, prócz zainteresowania dla człowieka o podobnych upodobaniach, prócz naturalnej życzliwości dla ładnej kobiety. K, 108 To jest bez wątpienia zupełnie sprytna strategia, ale my nie powinnyśmy brać się na to tak łatwo, powinnyśmy solidaryzować się wszystkie $w$ walce przeciw wspólnemu wrogowi. K, 110 
O tak - mówiła wczoraj - on jest pełnym człowiekiem - posiada wszystko: tam - cyganeria, hulanka, szerokie życie, śpiew, szampan, kwiaty, zapomnienie; tu - czysty, ciepły blask ognia domowego, rozkosze ojcostwa, kochająca, wierna kobieta... gdy jedno mu się znudzi - idzie po drugie... A my jesteśmy kalekami - wszystkie. K, 86

(...) by im zapewnić najobszerniejszą skalę wrażeń, by im pozwolić być pełnymi ludźmi. K, 86-7

Ich władza ma wymiar ludzki i boski, dlatego nazwani zostają zarówno królami, jak i panami życia i śmierci.

Swą cudowną, wytworną głowę tulił do mych kolan i cicho szeptał jakieś dziwne, czarowne, niedosłyszalne wyrazy! był jak król, który dość silny jest na to, by móc się ukorzyć. K, 129

A to wszystko dlatego, by ich - panów życia i śmierci - zabawiać efektem kontrastu, by im zapewnić najobszerniejszą skalę wrażeń, by im pozwolić być pełnymi ludźmi. K, 86-7

Obrazy mężczyzn pozbawionych majestatu i siły są tu bardzo rzadkie - choć mogą oni stać się zabawką w kobiecych dłoniach, ma to miejsce nieczęsto. Nałkowska nazywa ich wtedy zwierzątkiem lub dzieckiem:

Są rzeczy, których nie mówi się dzieciom.

A to jest jedyna droga do nich - ponieważ to wszystko są zwierzątka. K, 97

Osobną grupę stanowią określenia mężczyzn, będących obiektem kobiecych działań, środkiem służącym realizacji planu, medium do wprawek, opoką do uczepienia się:

T[rąbski?] wyjechał na posadę w Kieleckie - pewnie na długo. Był on dla mnie medium, wprawiałam się na nim. D, 25

Zresztą ja nie lubię mężczyzn kokietujących, tylko media - dla mojej kokieterii, takie, jakim jest Mędrzecki, wolę wzbudzać podziw niż podziwiać. D, 85 Muszę być zupełnie przygotowana na lekkie przejście rozstania - i zawczasu rozglądam się za jakąś opoką, której można by się było później uczepić. K, 173 
Choć kobiety Nałkowskiej nie ustępują mężczyznom w żadnej dziedzinie życia wewnętrznego, są w pełni świadome ograniczeń nakładanych na nie przez surową obyczajowość XIX wieku. Z tego względu choć mogłyby mężczyznami władać - niezwykle rzadko pokazywane są jako wojownicy czy zdobywcy, a więc w sytuacji zwycięstwa:

Rozkoszą wojownika nie jest zwycięstwo nad słabszym, lecz uwielbienie dla siły, która godna była go pokonać. K, 27

Ja mam dużo siły, długo mogę walczyć, ale przecież i wojownicy mają chwile, kiedy głowę zmęczoną kładą z bezgraniczną ufnością na czyichś kolanach, chwile, w których raz chociaż, na krótko - czują się bezpiecznymi, czują nad sobą kogoś, kto za nich czuwa, kto odgranicza ich od wroga, od nieskończoności i tajemnicy. K, 32

A jednak nie uczynię tego - $\mathrm{i}$ zawsze $\mathrm{z}$ ciasną dumą zdobywczyni serc będę się sama przed sobą chełpić tym, że w myślach jego zajmowałam pewne miejsce, że nazywał mię "oblubienicą bogów", uważał za piękność, jakiej podobnej nie widział nigdy żywej - tylko na obrazach starych mistrzów. D, 152

Znacznie częściej kobieta jest przedstawiana jako obiekt męskich poczynań, igraszek, istota zależna, pozostająca na męskich usługach, niekiedy wręcz - zwierzyna do upolowania. Silnie zakorzeniony w kulturze jest obraz kobiety jako męskiej ofiary i obleganej fortecy:

Kunszt kokietowania ofiar swych doprowadził do mistrzostwa. K, 88

Kobieta przywykła grać w miłości rolę obleganej fortecy - dlatego ilość jej miłości równa się ilości jej przegranych, dlatego, poddając się, ratuje swój honor wojenny ciężkimi warunkami kapitulacji. K, 107

Czyż to nie ta trwoga raczej, która w krew nam już weszła, trwoga przed rzeczywistością, czyż to nie wieczna potrzeba grania roli obleganej fortecy, która po to tylko broni swej niepodległości, by ją tym drożej utracić... K, 109

Do stereotypów sięga także Nałkowska przedstawiając kobiety jako zwierzynę, żer dla męskich łowców:

Zwierzyna jest mu różnie potrzebna, jak kobieta. K, 25

Paru panów podeszło przywitać się z nami. byli trochę zdziwieni i z pewnym rozrzewnieniem patrzyli na Ginę. Wyglądali, jakby węszyli żer. K, 157

Mężczyzna może być i prawie zawsze jest człowiek pełnym. Kobiecie zaś przypadł los człowieczej karykatury, istoty niepełnej - a więc lalki, 
kaleki, latawca na wietrze. Słownictwo tej grupy jest silnie nacechowane negatywnie:

O tak - mówiła wczoraj - on jest pełnym człowiekiem - posiada wszystko: tam - cyganeria, hulanka, szerokie życie, śpiew, szampan, kwiaty, zapomnienie; tu - czysty, ciepły blask ognia domowego, rozkosze ojcostwa, kochająca, wierna kobieta... gdy jedno mu się znudzi - idzie po drugie... A my jesteśmy kalekami - wszystkie. K, 86

A w domowym ognisku pali się szczęście innego rodzaju kaleki, dziwnego stworzenia, które niezdolne jest już do zstąpienia w odmęt życia, któremu to, co pogardą otaczano przez wieki, atawistycznie teraz wydaje się naprawdę wstrętnym... K, 86

Tam bawi się kosztem lalek, którym wydarto duszę, poczucie dostojeństwa ludzkiego, świadomość praw do życia, zdolność do miłości, wrażliwość na rozkosz, którym narzucono nieusprawiedliwioną pogardę dla siebie, bezustanne poczucie winy nie istniejącej, dla których pierwsza zmarszczka - jest wyrokiem śmierci. K, 86

A ja szamocę się w tej miłości, jak wzbity nad obłoki latawiec szamoce się na nitce, trzymanej w palcach przez rozbawione pacholę. $\mathrm{K}, 146$

Pełne człowieczeństwo nie jest jej nigdy dane, bo zarówno będąc kobietą-zwierzątkiem, jak i kobietą-człowiekiem jest się nadal tylko ludzką namiastką:

$\mathrm{Na}$ ten okres potrzebne im są tak zwane kobiety-zwierzątka; taka kobieta śmieje się, mieni, lśni przez parę lat - potem jest brzydka, zbiera naturalnie kości i żałuje, że poszła "taką drogą". K, 99

Dopiero gdy mężczyzna się już „wyszumi”, zgasi w sobie zwierzę, a obudzi - filistra, myśliciela, ojca, obywatela - wówczas wyciąga łapę po tak zwaną kobietę-człowieka (...) K, 99

Miłość jest pojęciem abstrakcyjnym, a zatem trudnym do wyrażenia słowami, co sprawia, że mówiąc o niej chętniej sięgamy po ekwiwalenty znaczeniowe (zwłaszcza metafory i symbole) niż werbalizujemy ją bezpośrednio. U zwykłych użytkowników języka są to przede wszystkim utrwalone i wielokrotnie powtarzane zestawienia słowne (metafory potoczne), w literaturze zaś spotykamy także metafory niekonwencjonalne, odwołujące się do indywidualnych wyobrażeń, poglądów czy przeżyć 
konkretnego twórcy. W przypadku Nałkowskiej tak licznemu stosowaniu metaforycznych obrazów - zarówno potocznych (czarować, uczynić niewolnikiem, utracić niepodległości, składać bron przed walkq, opierać się wszystkimi siłami, rasowe zwierzę, rozhukany kon, zdobywca serc), jak i niekonwencjonalnych (miłość patrzy obłakanymi z trwogi oczami, dusza wysuwa kolce, rozbroić krzykiem bólu lub trwogi, posag bazaltowy, latawiec na wietrze) - dodatkowo mógł sprzyjać fakt, że pod koniec XIX wieku sztuką zawładnął symbolizm, który wkradł się także do modernistycznej poezji i prozy.

Jak już parokrotnie wspominałam, w sposobie obrazowania miłości przez Nałkowską dominowało odwoływanie się do semantyki walki miłość oznaczała nieustanne zmagania kobiety i mężczyzny (miłość to walka, walczenie, wieczny antagonizm). Choć wyposażeni zostali oni przez naturę w równe siły, surowe normy obyczajowe sprawiały, że to kobiety częściej ponosiły klęskę i zmuszone były ulegać męskiej sile. Jednak nawet świadome tych nierównych szans (Nierówne sq szanse w walce kobiety $i$ mężczyzny. D, 24), za miłością wciąż podążały i od niej ginęły (W gruncie rzeczy wszystkie kobiety sq jednakowe - za jednym uganiaja się przez całe życie - $i$ od tego samego ginq - - K, 132).

\section{BEACAUSE LOVE BETWEEN MAN AND WOMAN IS WAR. WAYS OF PICTURING LOVE IN WORKS BY ZOFIA NALKOWSKA BASED ON WOMEN AND DIARIES}

\section{Summary}

This article is an attempt to reconstruction of ways in which Zofia Nalkowska pictured love in her modernist novel Kobiety and I volume of Diaries. The subject of the analysis were lexical exponents calling love and metaphoric pictures of love.

As the gathered material showed in Nalkowska's modernist works dominates picturing love as a battle, constant struggles between woman and man. Vocabulary calling women's and men's relations and metaphoric names of the sides of this love battle were used to represent it.

Due to the young age of the author we can assume that the way of picturing love wasn't a result of her own experience but cultural context (influence of modernist literature and art). 